\title{
HUBUNGAN TINGKAT PENGETAHUAN MASYARAKAT TENTANG FILARIASIS DENGAN PENCEGAHAN PENYAKIT FILARIASIS DI RW 05 KELURAHAN BEJI TIMUR KOTA DEPOK
}

\author{
Umi Bariyah Inayati ${ }^{1}$, Santi Herlina ${ }^{2}$ \\ 1. Program Studi S1 Keperawatan, FIKES UPN “Veteran” Pondok Labu, Jakarta Selatan - 12450, \\ Indonesia \\ 2. Keperawatan Medikal Bedah, Program Studi S1 Keperawatan, FIKES UPN "Veteran" Pondok Labu, \\ Jakarta Selatan - 12450, Indonesia
}

\begin{abstract}
The elephantiasis (filariasis) disease is a contagious chronically disease, which caused by filaria worm infection. The disease emerge symptom such as periodic fever, lymph gland chafe, edema.In the Depok city is included endemic area of filariasis. In Depok city, microfilaria rate is $>1 \%$ in October 2008. The purpose of this research is to identitify knowledge filariasis with the prevention filariasis desease. The method of this research is to use quantitative description and cross sectional approach. The method of collecting the data conducted by questionnaire and doing interview. Population were taken from the whole of society in the Rw 05 kelurahan Beji east Depok city with the taken sample 255 people.

The research variable consists of independent variable and dependent variable. Independent variable at this research is knowledge filariasis and dependent variable on this research is prevention program of filariasis desease.

From the research about the relationship of knowledge filariasis with the prevention filariasis desease there were relationship, existence of relation having a meaning of between knowledge with prevention program of filariasis desease in the Rw 05 kelurahan Beji east Depok city.

Suggest to the heath officer to improve their behavior by giving continues counseling, give optimum health service to the society, so that the people become sure on the given health service, and also to give interest and motivation for other researchers to improve the research output by doing deeper research in other place.
\end{abstract}

Key Word: Knowledge Filariasis, Prevention Program Of Filarisis Desease 


\section{PENDAHULUAN}

\section{Latar Belakang}

Kaki gajah (Filariasis) adalah penyakit menular yang disebabkan oleh cacing filarial yang hidup dalam kekenjar limfe dan pembuluh darah manusia yang ditularkan oleh sejenis nyamuk dan vektor . Cara penanggulangannya telah dilakukan antara lain dengan pengobatan menggunakan Diethylcarbamazine Citrate (DEC), dan Albanzole seerta pemberantasan Vektor. (Cermin Dunia Kedokteran no. 64,1990 15/Kasnodihardjo. dikutip pada tanggal 31 juli 2008). Di kota Depok sebanyak 11 warga kelurahan Tapos Cimanggis Depok positif mengidap penyakit filariasis. Hal itu diketahui dari sekitar 505 warga yang diambil sampel darahnya pada 24 oktober $2008>1 \%$ positif mengandung microfilaria.Penelitian dipusatkan di kecamatan Cimanggis, tepatnya $5 \mathrm{Rt}$ wilayah kelurahan Tapos yang telah dinyatakan endemis karena dari 505 warga yang diambil sampel darahnya $>$ $2,18 \%$ mengandung cacing filaria. Berdasarkan data kantor Dinas Kesehatan Depok, selain kelurahan Tapos, filariasis juga menyerang kecamatan limo khususnya kelurahan Duren Seribu, kelurahan Krukut, dan kelurahan Grogol sebanyak $1,83 \%$ sampel darah yang positif mengandung cacing filaria. Kemudian diikuti beberapa kecamatan lainnya seperti kecamatan Sukmajaya, kecamatan Beji dan kecamatan lainnya yang ditemukan rata-rata kejadian filariasis sama sebesar $>1 \%$ di temukannya microfilaria rate pada sampel darah penduduk di sekitar kasus Elephantiasis / Filariasis.

Berdasarkan data diatas diketahui bahwa kota Depok merupakan salah satu daerah endemis filarisis. Sampai saat ini pengetahuan masyarakat terhadap pencegahan filariasis masih kurang sehungga peneliti merasa tertarik untuk meneliti tentang hubungan tingkat pengetahuan masyarakat tentang filarirsis dengan pencegahan penyakit filariasis di Rw 05 kelurahan Beji Timur kota Depok.

\section{Rumusan Masalah.}

Dari hasil data yang diperoleh dari Departemen Kesehatan bahwa di Indonesia penyakit kaki gajah (filariariasis) mengalami peningkatan dari tahun ketahun, hal ini disebabkan karena kurangnya pengetahuan dan pemahaman warga terhadap penyakit filariasis, dan juga pencegahan terhadap penyakit filariasis.

Pada umumnya langkah kongkrit yang diambil oleh pemerintah untuk menanggulangi penyebaran penularan filariasis tersebut adalah dengan program pengobatan masal sebagai langkah untuk mencegah terjadinya penyakit filariasis.

Berdasarkan uraian diatas, maka dapat diasumsikan bahwa permasalahan mengenai tingkat pengetahuan masyarakat terhadap penyakit filariasis dan pencegahannya dipengaruhi oleh beberapa faktor, diantaranya adalah faktor kurangnya pengetahuan dan pemahaman warga tentang penyakit filariasis, dan pencegahannya. Adapun perumusan masalahnya adalah sebagai berikut :

1. Bagaimana tingkat pengetahuan masyarakat tentang penyakit filariasis

2. Bagaimana cara pencegahan penyakit filariasis

3. Adakah hubungan antara tingkat pengetahuan dengan pencegahan penyakit fariasis.

\section{Tujuan Penelitian.}

\section{Tujuan Umum}

Untuk mengetahui hubungan tingkat pengetahuan masyarakat tentang 
filariasis dengan pencegahan penyakit filariasis. di Rw 05 Kelurahan Beji Timur kecamatan Beji Depok.

\section{Tujuan khusus.}

a. Didapatkannya informasi mengenai karakteristik responden yang meliputi: umur, jenis kelamin, pekerjaan dan pendidikan.

b. Didapatkannya informasi mengenai karakteristik tentang pencegahan penyakit filariasis.

c. Didapatkannya informasi mengenai karakteristik tingkat pengetahuan masyarakat tentang penyakit filariasis.

d. Didapatkan informasi mengenai karakteristik hubungan tingkat pengetahuan dengan pencegahan penyakit filariasis

\section{TINJAUAN PUSTAKA}

\section{Konsep Filariasis}

Filariasis adalah penyakit menular menahun yang disebabkan oleh infeksi cacing filaria pada kelenjar/saluran getah bening, yang menimbulkan gejala klinik akut berupa demam berulang, peradangan kelenjar/saluran getah bening, oedema dan gejala klinis kronis berupa elephantiasis, hidrokel.

\section{Jenis Filariasis}

\section{a. Filariasis Bancrofti}

Adalah infeksi yang disebabkan oleh cacing nematoda Wuchereria bacrofti yang biasanya tinggal di sistem limfatik (saluran dan kelenjar limfa) dari penderita.

Perubahan patologi utama
disebabkan oleh kerusakan
pembuluh getah bening akibat
inflamasi yang di timbulkan oleh
cacing dewasa, bukan oleh
mikrofilaria. Cacing dewasa hidup di
pembuluh getah bening aferen atau
sinus kelenjar getah bening dan
menyebabkan pelebaran pembuluh
getah bening dan penebalan dinding
pembuluh. Infiltrasi sel plasma,
eosinofil, dan makrofag didalam dan
sekitar pembuluh getah bening yang
mengalami inflamasi bersama
dengan poliferasi sel endotel dan
jaringan penunjang, menyebabkan
berliku-likunya system limfatik dan
kerusakan atau inkompetensi katup
pembuluh getah bening. Perubahan-
perubahan yang terjadi akibat
filariasis ini disebabkan oleh efek
langsung dari cacing ini dan oleh
respon imun pejamu terhadap
parasit.

\section{2). Gejala Klinis}

Manifestasi dini penyakit ini adalah peradangan, sedangkan bila sudah lanjut akan menimbulkan gejala obstruksi. Adakalanya tidak menimbulkan gejala sama sekali terutama bagi penduduk yang dari kecil sudah berdiam di daerah endemik. Gejala peradangan tersebut sering timbul setelah bekerja berat dan dapat berlangsung antara beberapa hari hingga beberapa minggu (2-3 minggu). Gejala dari limfadenitis adalah nyeri lokal, keras di daerah kelenjar limfe yang terkena dan biasanya disertai demam, sakit kepala dan badan, muntah-muntah, lesu, dan tidak nafsu makan. Stadium akut ini lambat laun akan 1). bepalih ke stadium menahun dengan gejala-gejala hidrokel, kiluria, limfedema, dan elephantiasis

\section{b. Filpriasis Brugia Malayi}


Disebabkan oleh cacing nematode Brugia malayi dan brugia timori. Bentuknya periodik nokturnal dari Brugia Malayi di temukan pada masyarakat pedesaan yang tinggal di daerah persawahan terbuka yang sebagian besar ditemukan di Asia Tenggara.

\section{1). Patogenesis}

Parasit seperti $W$. bacrofti akan menimbulkan limfagitis dan elephantiasis. B. malayi berbeda dengan $W$. bacrofti dalam hal pasien dengan gejala filariasis yaitu mempunyai jumlah mikrofilaria yang lebih tinggi dibanding pasien yang tidak mempunyai gejala. Di Malaysia dengan perbandingan sampai 5 kali. Filariasis malayi khas dengan adanya limfadenopati super fisial dan dengan eosinofilia yang tinggi (7-70\%).

\section{2). Gejala Klinis.}

Gejala klinis filariasis malayi sama dengan gejala filariasis timori. Gejala klinis kedua penyakit tersebut berbeda dengan gejala klinis filariasis bancrofti. Stadium akut ditandai dengan serangan demam dan gejala peradangan saluran kelenjar limfe, yang hilang timbul berulang kali. Limfadenitis biasanya mengenai kelenjar limfe inguinal di satu sisi dan peradangan ini sering timbul setelah penderita bekerja berat di kebun atau sawah. Kadang-kadang peradangan pada kelenjar limfe ini menjalar kebawah, mengenai saluran limfe dan menimbulkan limfangitis retrograde, yang bersifat khas untuk filariasis. Peradangan pada saluran limfe ini dapat menjalar ke daerah sekitarnya dan menimbulkan infiltrasi pada seluruh paha atas. Pada stadium ini tungkai bawah biasanya ikut membengkak dan menimbulkan gejala limfadenitis.

\section{c. Filaria Brugia Timori}

Ditemukan di pulau Timor dan di bagian tenggara kepulauan Indonesia. Manifestasi klinis sama dengan infeksi yang terjadi pada Brugia malayi. Manifestasi klinis filariasis timbul tanpa ditemukannya mikrofalaria dalam darah (occult filariasis). Dari ribuan penderita dikalangan tentara Amerika yang di periksa selama perang dunia II, mikrofilaria ditemukan hanya pada 10-15 penderita dengan pemeriksaan darah berulang-ulang. Pada sebagian dari penderita tersebut, infeksi ditandai dengan eosinofilia yang sangat jelas terkandung disertai dengan gejala pada paru berupa sindroma "tropical pulmonary eosinophilia".

\section{Etiologi}

Cacing filaria merupakan nematode yang hidup di dalam jaringan subkutan dan sistem limfatik. Tiga spesies filaria yang menimbulkan infeksi pada manusia, Wuchereria Bancrofti, Brugia Malayi, dan Brugia Timori, merupakan penyebab infeksi filaria yang serius. oma "tropical pulmonary eosinophilia"

\section{Epidemiologi (Penyebaran Penyakit)}

Wuchereria bancrofti endemis disebagian besar wilayah di dunia di daerah dengan kelembaban yang cukup tinggi termasuk Amerika latin (fokus-fokus penyebaran yang tersebar di Suriname, Guyana, Haiti, Republik Dominika dan Costa Rica), Afrika, Asia dan Kepulauan Pasifik. Umumnya ditemukan di temukan di daerah perkotaan dengan kondisi ideal untuk perkembangan nyamuk. Brugia timari keberadaannya di daerah pedesaan di kepulauan Timor, Flores, Alor dan Rote di Tenggara Indonesia. Reservoir 
adalah manusia yang darahnya mangandung mikrofilaria $W$. bancrofti, Brugia Malayi (periodik) dan Brugia Timori. Di Indonesia dan beberapa Negara di temukan bahwa hewan seperti kucing, musang (Viverre tangalunga) dan kera dapat menjadi reservoir untuk Brugia malayi subperiodik.

\section{Diagnosis Filariasis}

\section{Radiodiagnosis}
a. Pemeriksaan ultrasonografi
dengan
(USG) pada skrotum dan kelenjar getah bening
b. Pemeriksaan limfasintigrafi dengan menggunakan dekstran atau albumin yang di tandai dengan adanya zat radioaktif.

\section{Diagnostik parasitologi}

Diagnosis dibuat berdasarkan gejalagejala klinis akut ataupun kronis, dengan dipastikan melalui pemeriksaan laboratorium. Pemeriksaan itu dilakukan dengan pengambilan darah pada jari penderita. Pemeriksaan dilakukan pada pukul 20.00 malam waktu setempat, karena pada saat malam hari mikrofilaria terdapat didalam tepi penderita. Apabila ternyata di dalam pemeriksaan sediaan darah tebal di temukan mikrofalaria, maka orang tersebut dinyatakan sebagai penderita filariasis atau kaki gajah.

\section{Cara Penularan}

Melalui gigitan nyamuk yang mengandung larva infektif. $W$. bancrofit di tularkan melalui berbagai spesies nyamuk, yang paling dominan adalah Culex quinquefasciatus, Anopheles gambiae, An. Funestus, Aedes polyneseiensis, An. Scapularis dan Ae. Pseudoscutellaris.
Cara penularannya tidak langsung dari orang ke orang, melainkan manusia dapat menularkan melalui nyamuk pada saat mikrofilaria berada pada darah tepi, mikrofilaria akan terus ada selama 5-10 tahun atau lebih sejak infeksi awal. Nyamuk akan menjadi infektif sekitar 1214 hari setelah menghisap darah yang terinfeksi.

\section{Konsep Pencegahan}

Cara pencegahan tersebut meliputi :

1. Memberikan penyuluhan kepada masyarakat di daerah endemis mengenai cara penularan dan cara pengendalian vektor (nyamuk).

2. Berusaha menghindari diri dari gigitan nyamuk vektor, misalnya: dengan menggunakan kelambu sewaktu tidur, menutup ventilasi rumah dengan kasa nyamuk, menggunakan obat nyamuk bakar atau semprot, mengoles kulit dengan obat anti nyamuk.

3. Peningkatan peran serta masyarakat dengan membentuk petugas Pengawas Minum Obat (PMO) untuk mengawasi / memantau penderita kaki gajah untuk meminum Obatnya secara teratur.

4. Mengidentifikasi vektor dengan mendeteksi adanya larva infektif dalam nyamuk dengan menggunakan umpan manusia, mengidentifikasi waktu dan tempat menggigit nyamuk serta tempat perkembangbiakannya. Jika penularannya terjadi oleh nyamuk yang menggigit pada malam hari di dalam rumah maka tindakan pencegahan yang dapat dilakukan adalah dengan penyemprotan, menggunakan pestisida residual, memasang kawat kasa, tidur dengan menggunakan kelambu (lebih baik yang sudah dicelup dengan insectisida piretroid), memakai obat gosok anti nyamuk (repellents) dan membersihkan tempat perindukan nyamuk seperti kakus yang terbuka, 
ban-ban bekas, batok kelapa, dan membunuh larva dengan larvasida. Jika ditemukan Mansonia sebagai vektor pada suatu daerah, tindakan yang dilakukan adalah dengan membersihkan kolam-kolam dari tumbuhan air (Pistia) yang menjadi sumber oksigen bagi larva tersebut.

5. Memberantas jentik-jentik nyamuk dengan membersihkan bak air di rumah.

6. Penerapan program 3M ( Menimbun, mengeringkan atau mengalirkan genangan air sebagai tempat perindukan nyamuk.)

7. Membersihkan semak-semak disekitar rumah.

8. Pengobatan massal filariasis

9. Depkes RI menetapkan kebijakan untuk program filariasis bahwa bila suatu desa Mf Rate nya $>1 \%$ maka daerah tersebut dinyatakan endemis filariasis dan harus dilakukan pengobatan massal terhadap seluruh penduduk desa tersebut. Berdasarkan hasil pemeriksaan tersebut maka daerah endemis filariasis harus segera dilakukan pengobatan massal untuk menurunkan angka prevalensi penyakit kaki gajah. Pengobatan massal filariasis adalah pengobatan yang dilaksanakan kepada seluruh penduduk di daerah endemis filariasis, yaitu daerah dengan angka mikrofaria rate $>1 \%$ dan dilaksanakan setahun sekali selama minimal lima tahun secara berturutturut. Pengobatan massal filariasis dilaksanakan dengan menggunakan obat Diethylcarbamazine Citrate (DEC) dan Albendazole yang terbukti efektif dalam memutus rantai penularan pada daerah yang endemis filariasis

10. Membersihkan lingkungan untuk mengurangi tempat perkembangbiakan nyamuk penular kaki gajah; peningkatan PSP masyarakat tentang penyakit kaki gajah melalui kegiata penyuluhan; peningkatan peran serta masyarakat dengan membentuk petugas Pengawas Minum Obat (PMO) untuk mengawasi / memantau penderita kaki gajah untuk meminum Obatnya secara teratur

11. Obat-obat yang digunakan untuk pengobatan filariasis :

- Diethylcarbamazine Citrate (DEC)

- Albendazole

\section{KERANGKA KONSEP, HIPOTESA DAN DEFINISI OPERASIONAL}

\section{Kerangka Konsep}

Kerangka konsep penelitian ini memiliki dua variabel, yaitu variabel independen dan variabel dependen. Variabel independent berisi tentang karakteristik responden ( diantaranya umur, jenis kelamin, pendidikan dan pekerjaan) dan tingkat pengetahuan masyarakat tentang filariasis (diantaranya Pengertian filariasis, jenis filariasis, etiologi, diagnosis, dan cara penularan). Sedangkan variabel dependen berisi tentang Pencegahan Filariasis (diantaranya mengidentifikasi vektor, memberantas jentik-jentik nyamuk, penerapan program $3 \mathrm{M}$, memberikan penyuluhan, dan pengobatan massal filariasis)

Pada penelitian ini sampel umur yang dipakai adalah dari umur 14 tahun sampai dengan 60 tahun.

\section{Hipotesa}

Sesuai dengan judul penelitian yang diambil yaitu "Hubungan tingkat pengetahuan masyarakat tentang filariasis dengan pencegahan penyakit filariasis di Rw 05 Kelurahan Beji Timur Kota Depok", maka hipotesa penelitian ini adalah: Ada hubungan antara tingkat 
pengetahuan masyarakat tentang penyakit filariasis dengan pencegahan penyakit filariasis di Rw 05 Kelurahan Beji Timur Kota Depok

\section{METODOLOGI}

\section{Desain Penelitian}

Penelitian ini menggunakan metode Deskriptif kuantitatif dengan pendekatan Croos Sectional, karena variabel independent dan dependent diobservasi satu kali secara bersamaan dan dalam waktu yang bersamaan. Data penelitian ini akan diperoleh berdasarkan satu kali survey dengan menggunakan kuesioner yang disebarkan kepada masyarakat di Rw 05 Beji Timur yang memenuhi kriteria sebagai responden. Selanjutnya data tersebut dijadikan dasar untuk mendeskripsikan karakteristik serta memperkirakan hubungan antara variabel dalam populasi berdasarkan data yang diperoleh dari sampel.

\section{Populasi dan Sampel Penelitian}

Populasi dalam penelitian ini di Rw 05 Kelurahan Beji Timur Kota Depok yang berjumlah 950 orang.

Teknik penentuan sampel dilakukan dengan Proportional Sampling, yaitu pengambilan sampel ini adalah bahwa setiap anggota dari populasi mempunyai kesempatan yang sama untuk diseleksi sebagai sampel.

Adapun teknik pengambilan sampelnya menggunakan accidental sampling, yaitu dilakukan dengan mengambil kasus atau responden yang kebetulan ada atau tersedia. Dengan taraf kesalahan $5 \%$ dimana hasil dari pengambilan sampel ini antara satu RT dengan RT lainnya yang berdomisili di Rw 05 kelurahan Beji Timur, Kota Depok akan berbeda, hal ini dilakukan dengan mempertimbangkan unsur validitas dari penelitian ini. Berikut pengambilan sampelnya: Bila jumlah populasi $=950$ dengan taraf kesalahan 5 $\%$ maka jumlah sampel 255

Rumus untuk menghitung ukuran sampel dari populasi yang diketahui jumlahnya adalah sebagai berikut:

$$
s=\frac{\lambda^{2} \cdot N \cdot P \cdot Q}{d^{2}(N-1)+\lambda^{2} \cdot P \cdot Q}
$$

Keterangan:

$\lambda^{2}$ dengan $\mathrm{dk}=1$, taraf kesalahan bisa $1 \%, 5 \%, 10 \%, \mathrm{~N}=$ Populasi,

$\mathrm{P}=\mathrm{Q}=0,5 . \quad \mathrm{d}=0,05 . \mathrm{s}=$ jumlah sampel.

\section{Lokasi Dan Waktu Penelitian}

Penelitian ini dilakukan di Rw 05 Kelurahan

Beji Timur Kota Depok, yang dilaksanakan dari bulan November 2008 sampai bulan Januari 2009.

\section{Cara Pengumpulan}

Pada penelitian ini data yang dikumpulkan berupa data primer yaitu data yang didapat dari hasil pengisian kuesioner. Pada pengisian kuesioner responden dibiarkan untuk mengisi angket sendiri. Hal ini agar reponden dapat lebih jujur dalam memberikan informasi, tanpa tekanan dari pihak manapun.

\section{Alat Pengumpulan Data}

Penelitian ini menggunakan alat pengumpulan data berupa kuesioner atau pertanyaan. Tujuannya adalah untuk mengetahui seberapa jauh responden paham tentang pertanyaan yang di ajukan.

Lembar kuesioner terdiri dari 30 pertanyaan, yang terdiri dari pertanyaan materi tentang pengetahuan filariasis sebanyak 15 soal, dan pertanyaan materi 
pencegahan filariasis sebanyak 15 soal. Sebelum pengumpulan data dilakukan uji coba untuk menghindari adanya kesulitan dalam mengartikan pertanyaan.

Uji coba dilakukan pada 30 orang yang bukan responden tetapi memiliki criteria yang sama, sedangkan waktu yang digunakan untuk pengisian kuesioner ini diperkirakan 15 menit setiap kuesionernya. Pengumpulan data dilakukan sendiri oleh peneliti.

\section{Hasil Uji Validitas Dan Reabilitas}

Untuk menguji validitas dan reabilitas alat, peneliti melakukan uji coba kuesioner. Uji kuesioner dilakukan dengan menyebarkan kuesioner pada orang yang mempunyai karakteristik hampir sama dengan responden yaitu masyarakat yang sesuai kriteria umur. Uji coba dilakukan untuk mengetahui sejauh mana pemahaman responden terhadap pertanyaan-pertanyaan dan validitas pertanyaan dari kuesioner yang telah dibuat.

Setelah kuesioner disebar pada sampel uji coba selanjutnya hasil tersebut diolah dengan komputer. Uji coba dilakukan untuk mengetahui sejauh mana pemahaman responden terhadap pertanyaan-pertanyaan yang ada dalam kuesioner dan validitas pertanyaan kuesioner yang telah dibuat. Dari hasil kuesioner maka dapat ditentukan beberapa pertanyaan yang dikurangi ataupun disesuaikan. Dari hasil uji reliabilitas untuk tingkat pengetahuan didapatkan hasil 0,813 dan untuk pencegahan didapatkan hasil 0,828. Sehingga berdasarkan tabel diatas keduanya memiliki hasil yang reliabel dan layak untuk disebarkan kepada responden.

\section{Pengolahan Data}

Metode pengolahan data yang digunakan oleh peneliti adalah Tabulasi dan SPSS, dengan langkah - langkah sebagai berikut

1. Editing

Peneliti melakukan pengecakan isian kuesioner, apakah sudah lengkap jawabannya, jelas terbaca, relevan dengan pertanyaannya serta konsisten jawaban antar pertanyaan satu dengan yang lainnya. Proses editing ini dilakukan di lapangan agar data yang salah satu atau meragukan masih dapat ditelusuri kembali kepada responden yang bersangkutan.

2. Coding

Peneliti merubah data berbentuk huruf menjadi data mempermudah pada saat analisis data dan juga mempercepat pada saat entry data. Kotak kode kuesioner dalam penelitian ini telah tersedia disebelah kanan pertanyaan.

3. Processing

Peneliti memasukkan data dari kuesioner ke penghitungan SPSS agar data dapat dianalisis.

4. Cleaning

Peneliti melakukan pengecekan kembali data yang sudah dientry untuk mengetahui kesalahan yang mungkin masih terjadi.

5. Tabulasi langsung

Tabulasi ini dilakukan dengan memasukkan data dari kuesioner kedalam kerangka tabel yang telah disiapkan, tanpa proses perantara yang lainnya. Tabulasi langsung biasanya dikerjakan dengan sistem tally yaitu cara menghitung data menurut klasifikasi yang telah ditentukan. Cara lain adalah kuesioner dikelompokkan menurut jawaban yang diberikan, kemudian dihitung jumlahnya, lalu dimasukkan ke dalam tabel yang telah disiapkan.

6. Komputer

Dengan menggunakan program SPSS (Statistical Program for Social 
Sciences). Dengan menggunakan program tersebut dapat dilakukan tabulasi sederhana. Tabulasi silang, regresi, korelasi, analisa faktor dan berbagai tes statistik.

\section{Analisa Data}

1. Analisa Univariat

Dilakukan untuk meringkas atau mendeskriptifkan data yang dikumpulkan melalui sampel yang diobservasi. Analisa univariat berfungsi untuk menggambarkan data yang merupakan jawaban responden yang diajukan. Analisa data univariat pada penelitian ini menggunakan distribusi frekuensi, presentase, dan kategorisasi data

2. Analisa Bivariat

Digunakan untuk menganalisa hubungan tingkat pengetahuan masyarakat tentang penyakit filariasis dengan pencegahan filariasis dengan menggunakan Chi Square melalui bantuan computer program window SPSS 13,0. Tingkat kepercayaan yaitu $\mathrm{P}=0,05$.

\section{Rumus Chi Square:}

$$
X^{2}=\frac{\sum(O-E)^{2}}{E}
$$

Keterangan:

$\mathrm{X}^{2}=$ Nilai Chi Square

$\sum=$ Penjumlahan

$\mathrm{O}=$ Frekuensi pengamatan untuk setiap kategori

$\mathrm{E} \quad=$ Frekuensi yang diharapkan untuk setiap

kategori

$\mathrm{DF}=(\mathrm{k}-1)(\mathrm{k}-\mathrm{b})$

Keterangan:

DF : degree of freedom (derajat kebebasan)

$\mathrm{K}$ : jumlah kolom

B: jumlah baris

\section{PEMBAHASAN}

\section{Keterbatasan Penelitian}

Beberapa keterbatasan penelitian yang ada sebagai berikut :

1. Keterbatsan waktu dan tenaga dari peneliti

2. Keterbatasan kuesioner

3. Keterbatasan Validitas Instrumen Penelitian

\section{Hasil Penelitian}

1. Jenis Kelamin

Responden dalam penelitian ini terdiri dari 255 orang yang diambil dari warga Rw 5 Kelurahan Beji Timur Kota Depok. Hasil analisa data dari jenis kelamin perempuan menunjukkan proporsi perempuan lebih banyak dibandingkan proporsi laki-laki, yaitu perempuan sebanyak 180 responden $(70,6 \%)$, dan yang berjenis kelamin laki-laki sebanyak 75 responden (29,4 \%). Hasil penelitian ini sesuai dengan beberapa penelitian, seperti yang dilakukan oleh Reyke Uloli, Soeyoko, Sumarni dengan judul "Analisis Faktor-faktor Resiko Kejadian Filariasis di Kabupaten Bone Bolango Propinsi Gorontalo Tahun 2004" dengan hasil penelitian proporsi penelitian lebih besar 36 responden $(51,4 \%)$ dibanding laki-laki 34 responden $(48,6 \%)$.

2. Usia

Usia responden dalam penelitian ini di bagi menjadi 3 kategori, yaitu usia 2 sampai 20 tahun, usia 21 sampai 40 tahun, dan usia 41 sampai 60 tahun. Dari kategori tersebut, prosentase tertinggi (65,9\% atau 168 responden) terdapat pada usia 21 tahun sampai 40 tahun, kemudian pada usia 2 sampai 20 tahun adalah sebanyak 77 responden atau 30,2 \%, dan paling sedikit prosentasenya terdapat pada usia 41 sampai 60 tahun yaitu 
sebanyak 10 responden $(3,9 \%)$. Hasil penelitian ini tidak jauh berbeda dengan beberapa penelitian, seperti yang dilakukan oleh Reyke Uloli, Soeyoko, Sumarni dengan judul "Analisis Faktor-faktor Resiko Kejadian Filariasis di Kabupaten Bone Bolango Propinsi Gorontalo Tahun 2004" yaitu usia 21 - 40 tahun sebanyak 28 responden (42,4 \%), yang kedua usia $41-60$ tahun sebanyak 20 responden $(30,3 \%)$, dan yang paling kecil pada usia $2-20$ tahun sebanyak 18 responden $(27,3$ $\%)$.

\section{Tingkat Pendidikan}

Tingkat pendidikan dalam penelitian ini dibagi menjadi 4 kategori, yaitu tamat SD, tamat SMP, tamat SMA, dan tamat Diploma/Perguruan Tinggi. Dari kategori tersebut, prosentase tertinggi $(68,6 \%$ atau 175 responden) terdapat pada tamatan SMA, yang kedua pada tamatan Diploma/Perguruan tinggi sebanyak 33 responden $(12,9 \%)$, ketiga pada tamatan SMP sebanyak 24 responden $(9,4 \%)$ dan yang keempat tamatan SD yaitu sebanyak 23 responden atau $9,0 \%$. Hasil penelitian ini sesuai dengan penelitian lainnya, seperti yang dilakukan oleh Lasbudi P.Ambarita yang berjudul "Peran serta Masyarakat (PSM) Dalam Penemuan Kasus Filariasis Di Desa Endemis Di Puskesmas Betung Kabupaten Banyuasin Tahun 2005" Bahwa Pendidikan responden sangat bervariasi dari yang tidak pernah sekolah sampai jenjang perguruan tinggi. Sebagian besar responden dengan tingkat pendidikan yang relatif rendah, yaitu tamat SD sebanyak $80 \%$.. sebagian besar responden $(77,6 \%) \quad$ pernah mendengar tentang filariasis (bahasa daerah "Tubuk"). Pengetahuan responden tentang agen penyebab filariasis masih rendah dimana hanya 19 responden (11,52\%) yang menjawab agen penyebab filariasis adalah cacing filaria.

\section{Tingkat pekerjaan}

Tingkat pekerjaan dalam penelitian ini dibagi menjadi 4 kategori, yaitu adalah tidak bekerja/rumah tangga, buruh, pegawai swasta, dan PNS/TNI/POLRI. Dari kategori tersebut, prosentase tertinggi $(72,5 \%$ atau 185 responden) terdapat pada yang tidak bekerja/rumah tangga, yang kedua pegawai swasta sebanyak 40 responden $(15,7 \%$, sebagai PNS/TNI/POLRI sebanyak 16 responden $(6,3 \%)$ dan yang keempat yang bekerja sebagai buruh yaitu sebanyak 14 responden $(5,5 \%)$.

Hasil penelitian ini tidak jauh berbeda dengan beberapa penelitian, seperti yang dilakukan oleh Lasbudi P.Ambarita yang berjudul "Peran serta Masyarakat (PSM) Dalam Penemuan Kasus Filariasis Di Desa Endemis Di Puskesmas Betung Kabupaten Banyuasin Tahun 2005" Bahwa mata pencaharian responden adalah bervariasi, dari yang bekerja sebagai petani $(72,4 \%$ atau 131 responden), rumah tangga $(13,4 \%$ atau 21 responden), wirausaha $(4,2 \%$ atau 7 responden), dan sebagai PNS/TNI/POLRI $\quad(3,0 \%$ atau 5 resposden)

5. Tingkat pengetahuan filariasis

Tingkat pengetahuan Warga Rw.05 Kelurahan beji timur tentang pengertian filariasis cukup baik, seperti yang terlihat di diagram 5 , bahwa sebagian besar $(56,5 \%$ atau 144 responden) menjawab dengan benar, yaitu filariasis adalah penyakit infeksi yang bersifat menahun yang disebabkan cacing filaria yang ditularkan melalui gigitan nyamuk. 
Dan sisanya 43,5 \% (111 responden) menjawab salah. Hasil penelitan ini sama seperti yang dilakukan oleh Lasbudi P.Ambarita yang berjudul "Peran serta Masyarakat (PSM) Dalam Penemuan Kasus Filariasis Di Desa Endemis Di Puskesmas Betung Kabupaten Banyuasin Tahun 2005" Bahwa sebagian besar responden $(77,6 \%)$ pernah mendengar tentang filariasis (bahasa daerah "Tubuk")..

Mengenai cara penularan filariasis dan siapa saja yang tertular, warga rw 5 kelurahan beji timur juga menunjukkan mempunyai pengetahuan yang cukup baik.Seperti yang terlihat pada diagram 7 , bahwa warga sebagian besar $(56,5 \%$ ayau 123 responden) menjawab dengan benar, yaitu cara penularan filariasis melalui Lewat gigitan nyamuk begitu juga warga sebagian besar $(53,7 \%$ atau 137 responden) menjawab dengan benar bahwa yang tertular filariasis adalah semua umur.

Peneltian ini sama seperti penelitian yang dilakukan oleh Lasbudi P.Ambarita (2005), bahwa sebagian besar $(45,9 \%$ atau 28 responden) mengatakan bahwa penularan filariasis disebabkan oleh gigitan nyamuk. Begitu juga pengetahuan masyarakat tentang siapa saja yang tertular filariasis, sebagian besar 29,7\% responden menyatakan bahwa semua golongan umur dapat tertular filariasis, namun hanya ada sekitar $18,8 \%$ menyatakan bahwa orang dewasa saja yang dapat tertular filariasis, sisanya orang lanjut usia 18 $\%$, anak-anak 4,7 \% dan tidak tahu $28,9 \%$.

Namun pengetahuan warga tentang gejala akut filariasis masih kurang baik, karena diantara mereka sebagian besar (51,8 \% atau 132 responden) masih menjawab salah, dan hanya sebanyak (48,\% atau 123 responden) yang menjawab benar, bahwa gejala yang ditimbulkan oleh penyakit filariasis adalah adanya urat seperti tali berwarna merah dan sakit (lihat diagram 8). Hasil peneltian ini sama dengan yang dilakukan oleh Lasbudi P.Ambarita yang berjudul "Peran serta Masyarakat (PSM) Dalam Penemuan Kasus Filariasis Di Desa Endemis Di Puskesmas Betung Kabupaten Banyuasin Tahun 2005" Bahwa Pengetahuan responden tentang gejala-gejala awal (gejala akut) filariasis sangat rendah dimana semua responden menyatakan bahwa gejala filariasis adalah pembengkakan pada bagian tubuh tertentu (elephantiasis). Hampir semua respoden $(79,26 \%)$ menyatakan bagian tubuh yang diserang/pembengkakan adalah kaki. Pemahaman seperti ini berkaitan dengan fakta bahwa yang umumnya mereka temukan adalah penderita dengan pembengkakan pada kaki.

Tentang gejala kronis (lihat diagram 10), seperti pembekakan pada kaki. Sebagian besar $(55,3 \%$ atau 141 responden) warga rw 5 kelurahan beji timur menjawab dengan benar, bahwa gejala kronis filariasis adalah pembesaran timbul di kaki, payudara, tangan, kantong zakar, alat kelamin wanita, dan lama-lama menjadi cacat menetap. Menurut mereka gejala kronik lebih terlihat, terutama seperti elephantiasis (kaki gajah) dibanding gejala akut. Hasil peneltian ini juga sama seperti yangg dilakukan oleh lasbudi P.Ambarita (2005), bahwa sebagian besar masyarakat mengetahui gejala kronik filariasis, yaitu pembengkakan pada kaki $(81,1$ $\%$, pembengkakan pada tangan $(1,9$ $\%)$ dan sisanya menjawab dengan jawaban lebih dari 1 (11,3\%).

Ketika warga ditanya lebih spesifik mengenai cacing apa yang menyebabkan filariasis, lihat diagram. 
12, mereka lebih banyak yang menjawab salah, yaitu sebanyak 50,2 \% (135 responden), sedangkan yang menjawab dengan benar sebanyak 49,8 \% (127 responden). Padahal mereka sudah pernah mengikuti penyuluhan (diagram 28). Seperti halnya penelitian yang dilakukan oleh lasbudi P. Ambarita (2005) bahwa meski ada sejumlah responden yang pernah mendapatkan penyuluhan tetapi pada saat wawancara ternyata responden tersebut tidak dapat memberikan jawaban yang benar. Hal ini dapat diakibatkan kemampuan responden tersebut terbatas dalam menyerap informasi yang diberikan pada saat penyuluhan dilakukan dan akibat lupa terhadap materi penyuluhan karena sudah lama dilakukan dan penyuluhan yang dilakukan tidak kontinu.

Mengenai langkah-langkah untuk mencegah penyakit filariasis, sebagian besar $(52,9 \%$ atau 135 responden) masih menjawab salah, dan hanya sebanyak (47,1\% atau 120 responden) yang menjawab benar bahwa langkah-langkah untuk mencegah penyakit filariasis yaitu dengan menghindari gigitan nyamuk (tidur dengan kelambu, menutup ventilasi dengan kasa, menggunakan obat nyamuk, memakai obat gosok anti nyamuk), menyemprot tempat perindukan nyamuk, dan mengikuti program 3M (lihat diagram 13). Sikap sebagian besar warga untuk mencegah filariasis dengan cara yang benar ternyata belum dilakukan. Seperti halnya penelitian yang dilakukan oleh Lasbudi P.Ambarita (2005) bahwa Kebiasaan responden pada malam hari umumnya sering keluar malam $(51,6 \%)$ dengan melakukan berbagai kegiatan. Kegiatan mereka di luar rumah pada malam hari adalah untuk ngobrol. Kegiatan malam hari di luar rumah ini memungkinkan kontak nyamuk vektor penular filariasis dengan manusia cukup tinggi, padahal upaya pencegahan untuk menghindari gigitan nyamuk masih kurang selama di luar rumah.

Pengetahuan masyarakat tentang upaya pemerintah untuk mencegah penularan penyakit filariasis belum banyak ditanggapi dengan benar, karena sebagian besar warga masih banyak yang menjawab salah yaitu sebesar (57,6\% atau 147 responden), lihat diagram 14. Begitu juga upaya pemerintah dalam memberikan pengobatan masal filariasis dengan memberikan obat secara cuma-cuma ternyata masih belum semua merespon dengan benar, karena sebagian besar $(56,5 \%$ atau 144 responden) warga menjawab salah. Hanya sebanyak 43,5 5 (111 responden) yang menjawab benar, pemberian obat secara cuma-cuma merupakan langkah awal untuk mencegah terjadinya penularan filariasis (lihat diagram 15). Mengenai pengetahuan siapa saja yang diperbolehkan mengkonsumsi obat filariasis, ternyata warga $\mathrm{Rw} 5$ kelurahan beji timur, masih banyak yang menjawab salah, yaitu sebanyak $52,2 \%$ (133 responden). Hal ini membuktikan bahwa ternyata pengetahuan masyarakat dalam menangani masalah filariasis belum semuanya benar, namun keinginan masyarakat untuk mengetahui lebih dalam tentang filariasis cukup tinggi (diagram 18), sehingga perlu dilakukan penyuluhan secara rutin dari petugas kesehatan. Seperti halnya penelitian oleh Subbid P2 Filariasis dan Schistosomiasis, Departemen Kesehatan RI pada tahun 1998-1999, yang berjudul "Global Strategi For Filariasis Control" dengan hasil: 1. sikap dan persepsi masyarakat terhadap filariasis masih kurang 
sebagai akibat dari masih rendahnya pengetahuan mereka terhadap penyakit itu. 2. Harapan masyarakat terhadap penanganan filariasis juga positif, namun memerlukan penyuluhan yang lebih digalakkkan untuk meningkatkan pengetahuan mereka.

6. Pencegahan penyakit filariasis

Sikap warga terhadap pencegahan penyakit filariasis cukup positif. Hampir semua warga menyatakan setuju terhadap pernyataan yang berhubungan dengan pencegahan filariasis. Pada diagram. 18 dapat dilihat bahwa warga begitu antusias mengikuti penyuluhan yang diadakan, karena sebagian besar $(68,6 \%$ atau 175 responden) warga $\mathrm{Rw} 05$ kelurahan beji timur pernah mengikuti penyuluhan tentang filariasis. Hasil penelitian ini sesuai dengan penelitian yang dilakukan oleh Lasbudi P.Ambarita yang berjudul "Peran serta Masyarakat (PSM) Dalam Penemuan Kasus Filariasis Di Desa Endemis Di Puskesmas Betung Kabupaten Banyuasin Tahun 2005" Bahwa sikap Sikap responden terhadap filariasis dalam hal pencegahan, pemeriksaan diri dan memakan obat dan upaya pemberantasan penyakit filariasis di daerahnya menunjukkan sikap yang positif . Salah satu cara untuk mengetahui sikap seseorang adalah dengan menanyakan pendapat orang yang bersangkutan tentang suatu hal. Hal yang positif adalah bahwa $80,4 \%$ responden menyatakan bahwa filariasis adalah penyakit yang berbahaya.. Sikap yang belum benar perlu diluruskan melalui kegiatan penyuluhan, hal ini dapat dilakukan oleh petugas kesehatan melalui kegiatan yang sering diadakan di desa seperti tahlilan dan sebagainya
Mengenai cara pencegahan yang mereka terapkan salah satunya adalah menggunakan kelambu dan obat nyamuk saat mereka, hal ini dapat dilihat pada diagram. 19, dimana sebagian besar $(63,5 \%$ atau 162 responden) mengatakan ya, dan hanya sebesar $(36,5 \%$ atau 93 responden) yang mengatakan tidak, terhadap penggunaan kelambu dan obat nyamuk saat mereka tidur. Begitu juga kebiasaan responden yang sering keluar rumah pada malam hari. Diagram. 21 menunjukkan bahwa warga sering keluar rumah pada malam hari sebesar 64,7 \% (165 responden). Panelitian ini tidak jauh berbeda seperti yang dilakukan oleh Lasbudi P.Ambarita yang berjudul "Peran serta Masyarakat (PSM) Dalam Penemuan Kasus Filariasis Di Desa Endemis Di Puskesmas Betung Kabupaten Banyuasin Tahun 2005" Bahwa Kebiasaan responden pada malam hari umumnya sering keluar malam $(51,6 \%)$ dengan melakukan berbagai kegiatan. Tindakan untuk menghindari gigitan nyamuk yang pada umumnya dilakukan responden adalah memakai obat nyamuk bakar $(43,8 \%)$. Kegiatan mereka di luar rumah pada malam hari adalah untuk ngobrol.

Kegiatan malam hari di luar rumah ini memungkinkan kontak nyamuk vektor penular filariasis dengan manusia cukup tinggi apabila upaya pencegahan untuk menghindari gigitan nyamuk masih kurang selama di luar rumah.

Untuk sikap warga terhadap pengambilan sampel darah dalam pemerikasaan filariasis, antusiasnya cukup, hal ini terbukti (seperti yang terlihat di digram.20), bahwa sebagian besar $(67,8 \%$ atau 173 responden) pernah diambil darahnya saat pemeriksaan filariasis, dan hanya 
sebanyak (32,2\% atau 82 responden) yang mengatakan tidak pernah diperiksa. Penelitian ini seperti yang dilakukan oleh Lasbudi P.Ambarita yang berjudul "Peran serta Masyarakat (PSM) Dalam Penemuan Kasus Filariasis Di Desa Endemis Di Puskesmas Betung Kabupaten Banyuasin Tahun 2005" Bahwa sebagian besar responden $(51,6 \%)$ pernah diperiksa darahnya untuk pemeriksaan filariasis.

Mengenai sikap warga ketika menemukan anggota keluarga mereka mengalami gejala-gejala filariasis sebagaian besar $(59,6 \%)$ atau 152 responden akan melaporkan kepada petugas kesehatan.dan hanya sebanyak (40,4 \%) atau 103 responden, mengatakan tidak melapor kepada petugas kesehatan. Penelitian ini tidak jauh berbeda dengan penelitian yang dilakukan oleh Lasbudi P.Ambarita (2005) bahwa tindakan pencarian pengobatan yang dilakukan responden pada umumnya $(86,7 \%)$ adalah melaporkan ke Puskesmas/Petugas Kesehatan apabila menderita atau mengetahui orang lain mengalami demam berulang selama 1-2 kali setiap bulan.

Pemberian obat filariasis (DEC) yang dilakukan oleh team dari puskesmas setempat, disambut positif oleh warga, sebagian besar warga $(61, \%$ atau 156 responden) mengatakan meminum paket obat filariasis dari puskesmas. Mengenai penyuluhan tentang filariasis, sebagian besar (56,1\% atau 143 responden) warga rw 5 kelurahan beji timur, mengatakan rutin dilakukan penyuluhan tentang filariasis. Seperti halnya yang dilakukan oleh Subbid P2 Filariasis dan Schistosomiasis, Dinas kesehatan RI pada tahun 1998 - 1999 telah melakukan uji coba pemakaian DECgaram beryodium di jambi, bahwa sikap dan persepsi masyarakat terhadap pemberian obat filariasis (DEC-garam beryodium) cukup positif sebagai akibat dari manfaat yang mereka alami yaitu tidak ada efek samping serta mudahnya memperileh DEC-garam beryodium tersebut. Harapan masyarakat di jambi, menegenai penangan filariasis juga positif, namun memerlukan penyuluhan yang lebih digalakkan untuk meningkatkan pengetahuan mereka. Harapan masyarakat terhadap penanganan filariasis juga positif, namun memerlukan penyuluhan yang lebih digalakkan untuk meningkatkan pengetahuan mereka.

\section{PENUTUP}

\section{Kesimpulan}

Sesuai dengan tujuan dari penelitian ini yaitu untuk mengetahui hubungan tingkat pengetahuan masyarakat tentang filariasis dengan pemberantasan penyakit filarisis di Rw 05 Kelurahan Beji Timur Kecamatan Beji Kota Depok, maka dapat disimpulkan sebagai berikut, terdapat hubungan yang bermakna antara tingkat pengetahuan masyarakat tentang filariasis dengan pencegahan filariasis di Rw 05 Kelurahan Beji Timur Kota depok dengan nilai kemaknaan probabilitas (Asymp Sig) 0,001<0,05.

\section{DAFTAR PUSTAKA}

Ambarita, Lasbudi P. (2005) Peran Serta Masyarakat (PSM) Dalam Penemuan Kaus Filariasis Di Desa Endemis Di Puskesmas Betung Kabupaten Banyuasin Tahun 2005. Staf Peneliti Loka Litbang P2B2 Baturaja. http://www.litbang.depkes.go.id/lok abaturaja 
Arikunto Suharsimi. (2002). Prosedur Penelitian. Revisi V. Rineka Cipta :Yogyakarta

Chin, James. (2006). Manual Pemberantasan Penyakit Menular. Jakarta : Infomedikasi

Candra, Dr. Budiman, (1995). Pengantar Statistik Kesehatan. Jakarta : EGC.

Departemen Kesehatan RI, (2005). Pedoman Penatalaksanaan Kasus Klinis Filariasis, Direktorat Jenderal $P P \& P L$, Jakarta.

Departemen Kesehatan RI, (2007). Pedoman Penanggulangan Kejadian Ikutan Pasca Pengobatan Filarisasis

Departemen Kesehatan, (2003). Pemberantasan Penyakit Menular dan Penyehatan Lingkungan (PPM dan $P L)$

Effendi, Nasrul. (1998). Dasar-Dasar Keperawatan Kesehatan Masyarakat. Edisi 2. EGC ; Jakarta

Herdiman T.P. (1999). Buku Ajar Penyakit Dalam Jilid I. Jakarta : Balai Penerbit FKUI.

Notoatmodjo, Soekidjo. (2000). Prinsipprinsip Dasar Ilmu Kesehatan Masyarakat. Jakarta: Rineka Cipta.

Notoatmodjo, Soekidjo. (2005). Metodologi Peneltian Kesehatan. Jakarta: Rineka Cipta

Nursalam, (2001). Pendekatan Praktis Metodologi Riset Keperawatan. Jakarta : CV, Sagung Seto

Sugiyono, (2007). Metode penelitian Kuantitatif Kualitatif Dan R Dan D Bandung: Alfabeta
Slamet, Soemirat, (1998). Kesehatan Lingkungan. Yogyakarta : Gajah Mada University Press

Siregar, Charles. (2006). Farmasi Klinik Teori dan Penerapan. Jakarta: EGC

Sastroatmodjo S., Ismail. (2002). Dasardasar Metodologi Penelitian Klinis, Edisi ke-2, Sagung Seto, Jakarta.

Soedarto. (1999). Penyakit-Penyakit Infeksi di Indonesia. Jakarta : Widya Medika.

Soeyoko. (2002). Penyakit Kaki Gadjah (Filariasis Limfatik) : Permasalahan dan Alternatif Penanggulangannya, Universitas Gadjah Mada.

Waluto, Jangkung Samidjo. (2002). Parasitologi Medik (Helmintologi): Pendekatan Aspek Identifikasi, Diagnosis, dan Klinik. Penerbit Buku Kedokteran Jakarta : EGC

Walpole, Ronald E. (1999). Pengantar Statistik. Edisi 3 . Jakarta : Gramedia Pustaka Utama

World Health Organization (2001) Regional Office For Sounth - East Asia : Regional Strategi Plan For Elimination of Lymphatic Filariasis (2000 - 2004). New Delhi.

Karnodjiharjo.(2008), Aspek sosio budaya dalam penanggulangan filariasis http://www. Cermin Dunia Kedokteran, Diakses tanggal 20 oktober 2008

Pustekkom, (2008).Filariasis http://www.e-Edukasi.net/mapok/mpfiles/swflf47.swf, Diakses tanggal 26 September 2008

Syahrul. (2002) Epidemiologi Filariasis di Desa Subgai Rengit Banyuasin http://www.e-Edukasi.net/mapok/mp- 
files/swf/f47.swf/Document

Settings. Diakses

tanggal

and

September 2008

Suddid P2 Filariasis dan Schistosomiasis,

Dit P2B2, Ditjen PPM \& PLP

Departemen Kesehatan RI (19981999). Global Strategi For Filariasis

Control. Bandung: ITB Central Library (http://digilib.itb.ac.id/gdl)

Sugiyono (2006). Metode Penelitian Kuantitatif Kualitatif dan $R$ \& D. Bandung : ALFABETA.

Triton P. (2005). SPSS 13.0 Terapan Riset Statistik Parametrik. Yogyakarta : CV.ANDI OFFSET.

Usman, Husaini. (2006). Pengantar Statistika Edisi ke 2. Yogyakarta : Bumi Aksara

ReykeUloli, Soeyoko, Sumarni (2004). Analisa Faktor-faktor Resiko Kejadian Filariasis DiKabupaten Bone Bolango Propinsi Gorontalo 